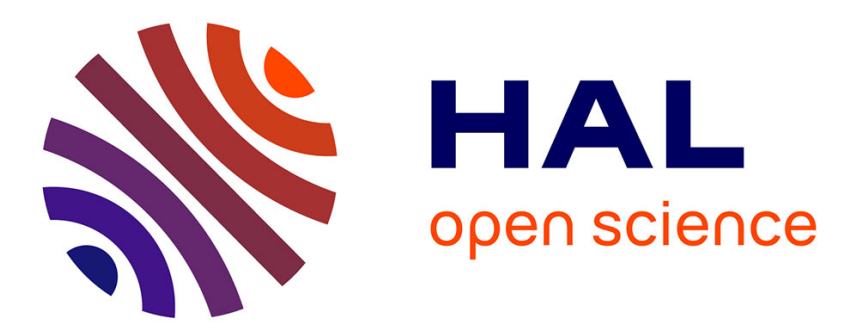

\title{
Relationship between low magnesium status and TRPM6 expression in the kidney and large intestine
}

Lusliany Rondón, Wouter M. Tiel Groenestege, Yves Rayssiguier, Andrzej

Mazur

\section{- To cite this version:}

Lusliany Rondón, Wouter M. Tiel Groenestege, Yves Rayssiguier, Andrzej Mazur. Relationship between low magnesium status and TRPM6 expression in the kidney and large intestine. AJP - Regulatory, Integrative and Comparative Physiology, 2008, 294 (6), pp.R2001-R2007. 10.1152/ajpregu.00153.2007 . hal-02666089

\section{HAL Id: hal-02666089 \\ https: / hal.inrae.fr/hal-02666089}

Submitted on 31 May 2020

HAL is a multi-disciplinary open access archive for the deposit and dissemination of scientific research documents, whether they are published or not. The documents may come from teaching and research institutions in France or abroad, or from public or private research centers.
L'archive ouverte pluridisciplinaire HAL, est destinée au dépôt et à la diffusion de documents scientifiques de niveau recherche, publiés ou non, émanant des établissements d'enseignement et de recherche français ou étrangers, des laboratoires publics ou privés. 


\section{Lusliany J. Rondón, Wouter M. Tiel Groenestege, Yves Rayssiguier and Andrzej}

Mazur

Am J Physiol Regulatory Integrative Comp Physiol 294:2001-2007, 2008. First published Apr 2, 2008; doi:10.1152/ajpregu.00153.2007

You might find this additional information useful...

This article cites 46 articles, 24 of which you can access free at:

http://ajpregu.physiology.org/cgi/content/full/294/6/R2001\#BIBL

This article has been cited by 2 other HighWire hosted articles:

Molecular identification of ancient and modern mammalian magnesium transporters

G. A. Quamme

Am J Physiol Cell Physiol, March 1, 2010; 298 (3): C407-C429.

[Abstract] [Full Text] [PDF]

Dysregulation of Vascular TRPM7 and Annexin-1 Is Associated With Endothelial

Dysfunction in Inherited Hypomagnesemia

T. M. Paravicini, A. Yogi, A. Mazur and R. M. Touyz

Hypertension, February 1, 2009; 53 (2): 423-429.

[Ästract] [Full Text] [PDF]

Updated information and services including high-resolution figures, can be found at:

http://ajpregu.physiology.org/cgi/content/full/294/6/R2001

Additional material and information about American Journal of Physiology - Regulatory, Integrative and Comparative Physiology can be found at:

http://www.the-aps.org/publications/ajpregu

This information is current as of September 7, 2010 .

The American Journal of Physiology - Regulatory, Integrative and Comparative Physiology publishes original investigations that illuminate normal or abnormal regulation and integration of physiological mechanisms at all levels of biological organization, ranging from molecules to humans, including clinical investigations. It is published 12 times a year (monthly) by the American

Physiological Society, 9650 Rockville Pike, Bethesda MD 20814-3991. Copyright @ 2008 by the American Physiological Society. ISSN: 0363-6119, ESSN: 1522-1490. Visit our website at http://www.the-aps.org/. 


\title{
Relationship between low magnesium status and TRPM6 expression
}

\section{in the kidney and large intestine}

\author{
Lusliany J. Rondón, ${ }^{\mathbf{1}}$ Wouter M. Tiel Groenestege, ${ }^{\mathbf{2}}$ Yves Rayssiguier, ${ }^{\mathbf{1}}$ and Andrzej Mazur ${ }^{\mathbf{1}}$ \\ ${ }^{1}$ Institut National de la Recherche Agronomique, Unité de Nutrition Humaine, Centre de Recherche en Nutrition Humaine \\ d'Auvergne, Theix, St Genès Champanelle, France; and ${ }^{2}$ Department of Physiology, Nijmegen Centre for Molecular Life \\ Sciences, Radboud University Nijmegen Medical Centre, Nijmegen, The Netherlands
}

Submitted 2 March 2007; accepted in final form 26 March 2008

\begin{abstract}
Rondón LJ, Groenestege WM, Rayssiguier Y, Mazur A. Relationship between low magnesium status and TRPM6 expression in the kidney and large intestine. Am J Physiol Regul Integr Comp Physiol 294: R2001-R2007, 2008. First published April 2, 2008; doi:10.1152/ajpregu.00153.2007.-The body maintains $\mathrm{Mg}^{2+}$ homeostasis by renal and intestinal (re)absorption. However, the molecular mechanisms that mediate transepithelial $\mathrm{Mg}^{2+}$ transport are largely unknown. Transient receptor potential melastatin 6 (TRPM6) was recently identified and shown to function in active epithelial $\mathrm{Mg}^{2+}$ transport in intestine and kidney. To define the relationship between $\mathrm{Mg}^{2+}$ status and TRPM6 expression, we used two models of hypomagnesemia: 1) C57BL/6J mice fed a mildly or severely $\mathrm{Mg}^{2+}$-deficient diet, and 2) mice selected for either low $(\mathrm{MgL})$ or high $(\mathrm{MgH})$ erythrocyte and plasma $\mathrm{Mg}^{2+}$ status. In addition, the mice were subjected to a severely $\mathrm{Mg}^{2+}$-deficient diet. Our results show that C57BL/6J mice fed a severely $\mathrm{Mg}^{2+}$-deficient diet developed hypomagnesemia and hypomagnesuria and showed increased TRPM6 expression in kidney and intestine. When fed a $\mathrm{Mg}^{2+}$-adequate diet, $\mathrm{MgL}$ mice presented hypomagnesemia and hypermagnesuria, and lower kidney and intestinal TRPM6 expression, compared with $\mathrm{MgH}$ mice. A severely $\mathrm{Mg}^{2+}$-deficient diet led to hypomagnesemia and hypomagnesuria in both strains. Furthermore, this diet induced kidney TRPM6 expression in MgL mice, but not in $\mathrm{MgH}$ mice. In conclusion, as shown in $\mathrm{C} 57 \mathrm{BL} / 6 \mathrm{~J}$ mice, dietary $\mathrm{Mg}^{2+}$-restriction results in increased $\mathrm{Mg}^{2+}$ (re)absorption, which is correlated with increased TRPM6 expression. In MgL and MgH mice, the inherited $\mathrm{Mg}^{2+}$ status is linked to different TRPM6 expression. The $\mathrm{MgL}$ and $\mathrm{MgH}$ mice respond differently to a low- $\mathrm{Mg}^{2+}$ diet with regard to TRPM6 expression in the kidney, consistent with genetic factors contributing to the regulation of cellular $\mathrm{Mg}^{2+}$ levels. Further studies of these mice strains could improve our understanding of the genetics of $\mathrm{Mg}^{2+}$ homeostasis.
\end{abstract}

low $\mathrm{Mg}^{2+}$ diet; low $\mathrm{Mg}^{2+}$ inbred mice; active $\mathrm{Mg}^{2+}$ (re)absorption

ONE OF THE MOST ABUNDANT CATIONS in the body is $\mathrm{Mg}^{2+} \cdot \mathrm{Mg}^{2+}$ is a cofactor for numerous enzymes and is required for many biological processes. It is essential for activation of many ATPases, including the $\mathrm{Na}^{+} / \mathrm{K}^{+}$and $\mathrm{Ca}^{2+}$ ATPases, and more than 300 other enzymes $(1,31) . \mathrm{Mg}^{2+}$ homeostasis is maintained by renal and intestinal absorption $(22,23)$.

The kidney is crucial for $\mathrm{Mg}^{2+}$ homeostasis. About $70 \%$ of $\mathrm{Mg}^{2+}$ is ultrafiltrable in the glomeruli (23), and $80-99 \%$ is reabsorbed in the nephron segments (29). $\mathrm{Mg}^{2+}$ reabsorption in the kidney is mainly achieved by the paracellular pathway in the cortical thick ascending limb (cTAL $\pm 60 \%$ ) (8). The distal convoluted tubule (DCT) is the critical segment of the nephron (28) where final $\mathrm{Mg}^{2+}$ reabsorption occurs (10-15\%) and final

Address for reprint requests and other correspondence: Correspondence: Mazur A. INRA, Unité de Nutrition Humaine, Centre de Recherche en Nutrition Humaine d'Auvergne, Theix, 63122 St. Genès Champanelle, France (e-mail: mazur@clermont.inra.fr). excretion is determined. In the mammalian intestine, $\mathrm{Mg}^{2+}$ absorption is almost exclusively passive, by a nonsaturable paracellular pathway. Active intestinal $\mathrm{Mg}^{2+}$ absorption is important when dietary $\mathrm{Mg}^{2+}$ intake is extremely low $(13,22)$.

$\mathrm{Mg}^{2+}$ deficiency can result from low $\mathrm{Mg}^{2+}$ intake or depletion, typically related to gastrointestinal or renal loss (23). Nowadays, clinical symptoms of $\mathrm{Mg}^{2+}$ deficiency are rarely recorded. However, a high prevalence of hypomagnesemia has been reported in western countries, and a link between low $\mathrm{Mg}^{2+}$ intake and chronic disease has been established (34).

$\mathrm{Mg}^{2+}$ status is determined by a combination of environmental (including nutrition) and genetic factors, which regulate $\mathrm{Mg}^{2+}$ metabolism (10). Henrotte et al. (18) studied inherited hypomagnesemia in populations with genetically induced low $\mathrm{Mg}^{2+}$ status and found a polygenic influence and probably polymorphisms in the genes responsible for $\mathrm{Mg}^{2+}$ homeostasis. Recently, different genetic diseases that specially interfere with $\mathrm{Mg}^{2+}$ (re)absorption and retention have been described, and a number of genes involved in $\mathrm{Mg}^{2+}$ homeostasis discovered: CLDN16 (PCLN1), FXYD2, CASR, CLCNKB, SLC12A3, and TRPM6. Mutations in these genes can cause $\mathrm{Mg}^{2+}$ metabolism disorders $(5,22,23,35)$. In familial hypomagnesemia with secondary hypocalcemia (HSH), transient receptor potential melastatin 6 (TRPM6) was identified as the first component directly involved in active kidney and intestinal epithelial $\mathrm{Mg}^{2+}$ (re)absorption $(36,46)$.

TRPM6 is a member of the TRP channel family. It has a high affinity for $\mathrm{Mg}^{2+}$, resides in the apical membrane of kidney and intestinal epithelial cells (mainly the large intestine), and functions in active transepithelial transport. TRPM6 is expressed along the entire gastrointestinal tract (GIT) (36), in lung and in kidney (predominantly in the DCT) $(4,8,14,27)$. TRPM6 expression is sensitive to intracellular $\mathrm{Mg}^{2+}$ levels and plays an important role in $\mathrm{Mg}^{2+}$ reabsorption and excretion at critical reabsorption sites (DCT). This suggests that TRPM6 is a key component in the maintenance of $\mathrm{Mg}^{2+}$ homeostasis. Furthermore, another member of the TRP family, the ubiquitously expressed TRP melastatin 7 (TRPM7), is necessary for cellular $\mathrm{Mg}^{2+}$ and $\mathrm{Ca}^{2+}$ conservation $(15,39,42)$.

The goal of this study was to determine the role of TRPM6 in active transepithelial transport in selected tissues (kidney, cecum, colon, and lung) and in $\mathrm{Mg}^{2+}$ homeostasis. To address these questions, we studied two low- $\mathrm{Mg}^{2+}$ status models: 1) graded dietary $\mathrm{Mg}^{2+}$ restriction in $\mathrm{C} 57 \mathrm{BL} / 6 \mathrm{~J}$ mice and 2) inbred mice strains selected for high and low erythrocyte $\mathrm{Mg}^{2+}$

The costs of publication of this article were defrayed in part by the payment of page charges. The article must therefore be hereby marked "advertisement" in accordance with 18 U.S.C. Section 1734 solely to indicate this fact. 
levels (MgH and $\mathrm{MgL}$, respectively). The MgL mice had inherited hypomagnesemia, consistent with a genetic defect in $\mathrm{Mg}^{2+}$ handling, and therefore their response to $\mathrm{Mg}^{2+}$ deficient diet was evaluated.

\section{MATERIALS AND METHODS}

Animals

Experiment 1. Female C57BL/6J mice, between 4 and 6 mo old, were used. During the first week of the experiment, the mice were fed a control diet $\left(0.1 \% \mathrm{Mg}^{2+} \mathrm{wt} / \mathrm{wt}\right)$. Then, the mice were randomly divided into three groups and over the following $2 \mathrm{wk}$, each group received one of three diets: a control diet $\left(0.1 \% \mathrm{Mg}^{2+} \mathrm{wt} / \mathrm{wt}\right)$, a mildly $\mathrm{Mg}^{2+}$-deficient diet $\left(0.01 \% \mathrm{Mg}^{2+} \mathrm{wt} / \mathrm{wt}\right)$ or a severely $\mathrm{Mg}^{2+}$-deficient diet $(0.003 \%$ $\mathrm{Mg}^{2+} \mathrm{wt} / \mathrm{wt}$ ). The $\mathrm{Ca}^{2+}$ content of the diets was $0.4 \%$ (wt/wt). All diets were prepared in our laboratory. Distilled water and food were available ad libitum. The mice were housed in metabolic cages during the last three days of the experiment, and urine samples were collected. At the end of the experiment, the animals were killed and blood (collected from the heart), kidney, cecum, colon, and lungs were collected for further analysis. Tissues were immediately frozen in liquid nitrogen.

Experiment 2. Female mice were selected for high $(\mathrm{MgH})$ or low (MgL) erythrocyte $\mathrm{Mg}^{2+}$ levels $(10,11,17)$, using our breeding colony. The animals were between 4 and 6 mo of age. During the first week of the experiment, the mice were fed a control diet $\left(\mathrm{Mg}^{2+}\right.$ and $\mathrm{Ca}^{2+}$ content as above). Then, the $\mathrm{MgH}$ and $\mathrm{MgL}$ mice were divided into two different groups, and during the following $2 \mathrm{wk}$, each group received one of two diets: a control diet $\left(0.1 \% \mathrm{Mg}^{2+} \mathrm{wt} / \mathrm{wt}\right)$ or a severely $\mathrm{Mg}^{2+}$-deficient diet $\left(0.003 \% \mathrm{Mg}^{2+}\right.$ wt/wt). Distilled water and food were available ad libitum. During the last three days of the experiment, the animals were housed in metabolic cages, and samples were collected as described above.

All animals were housed in temperature-controlled rooms $\left(22^{\circ} \mathrm{C}\right)$, with a 12:12-h light-dark cycle and handled according to the recommendations of the Institutional Ethics Committee (Institut National de la Recherche Agronomique, Theix, France) and decree no. 87-848.

\section{Plasma and Erythrocyte Collection}

Blood from the heart was collected in heparin-containing tubes. Plasma was obtained by centrifugation $\left(10 \mathrm{~min}, 3,500 \mathrm{rpm}, 4^{\circ} \mathrm{C}\right)$ and frozen for later analysis. For erythrocyte $\mathrm{Mg}^{2+}$ determination, erythrocytes were washed three times with saline solution and then hemolyzed in water-containing tubes.

\section{Creatinine Analysis}

Urine was diluted 20 times, and the creatinine content was determined using an automated chemical analysis kit, following the manufacturer's instructions (Kone Progress Plus, Kone Instruments Oy, Espoo, Finland).

\section{Mineral Analysis}

Plasma, erythrocyte (only $\mathrm{Mg}^{2+}$ ) and urine $\mathrm{Mg}^{2+}$ and $\mathrm{Ca}^{2+}$ concentrations were determined after dilution with $0.1 \%(\mathrm{w} / \mathrm{v}) \mathrm{LaCL}_{3}(9$, 11). Plasma and urine $\mathrm{K}^{+}$and $\mathrm{Na}^{+}$concentrations were determined after dilution with $0.1 \%(\mathrm{w} / \mathrm{v}) \mathrm{CsCl}$.

The mineral contents were determined by atomic absorption spectrophotometry (using a Perkin-Elmer AA800, Quebec, Canada) at 285 $\mathrm{nm}, 423 \mathrm{~nm}, 589 \mathrm{~nm}$, and $767 \mathrm{~nm}$ for $\mathrm{Mg}^{2+}, \mathrm{Ca}^{2+}, \mathrm{Na}^{+}$, and $\mathrm{K}^{+}$, respectively.

\section{Quantitative Real-Time PCR Analysis}

Total RNA was extracted from complete segments of kidney, cecum, and colon using the TRIzol Total RNA Isolation Reagent
(Life Technologies BRL, Breda, the Netherlands), following the manufacturer's protocol. Subsequently, DNAse treatment (Promega, Madison, WI) was performed to eliminate genomic DNA contamination. Two micrograms of RNA was used for reverse transcriptase reactions with the Moloney murine leukemia virus reverse transcriptase (Life Technologies), as previously described (20). The expression levels of TRPM6 and TRPM7 were determined by quantitative real-time PCR in kidney, cecum, and colon, using an ABI Prism 7700 sequence detection system (PE Biosystems, Rotkreuz, Switzerland). The expression level of the housekeeping gene hypoxanthine-guanine phosphoribosyl transferase (HPRT) was used as a control. Primers and probes for the target genes were designed using the Primer Express software as previously described (14).

\section{Immunohistochemistry (IHC)}

Cryosections (7- $\mu \mathrm{m}$-thick) of periodate-lysine-paraformaldehydefixed kidney were stained as previously described $(20,44,45)$. The
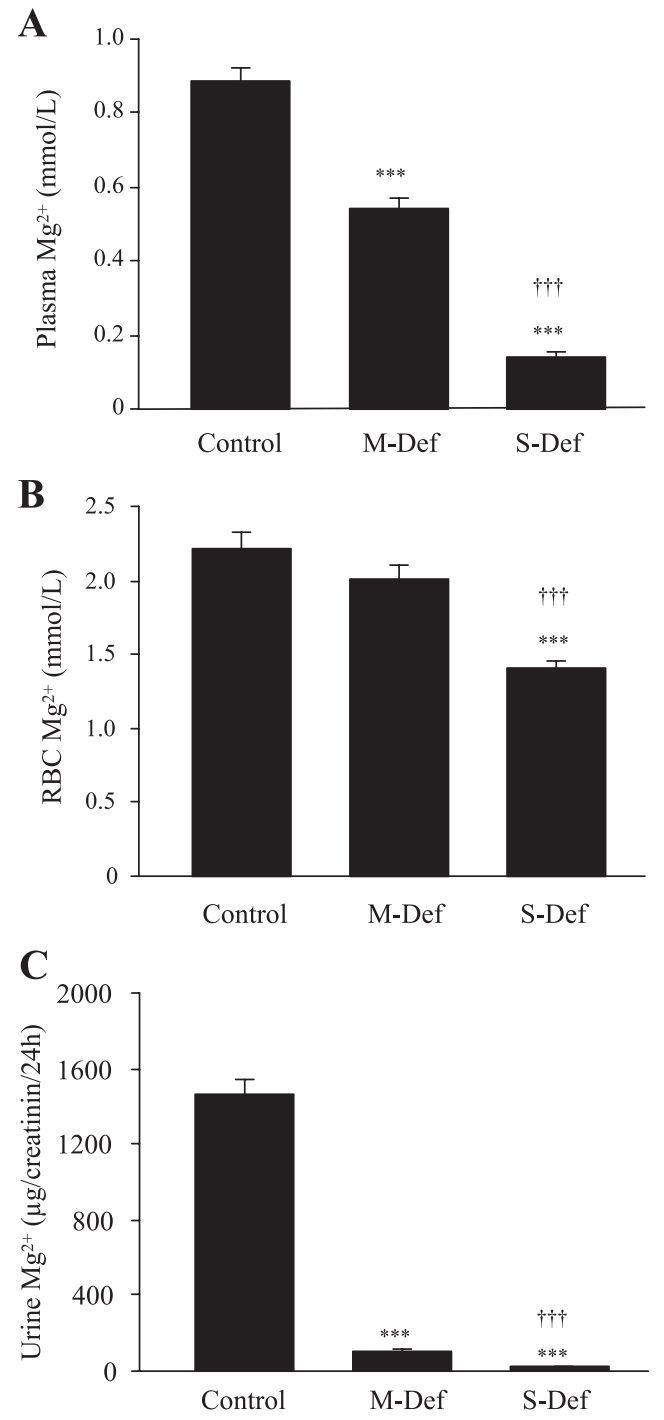

Fig. 1. Plasma, erythrocyte, and urinary $\mathrm{Mg}^{2+}$ concentrations in mice fed a control, moderate (M-Def) or severely (S-Def) $\mathrm{Mg}^{2+}$-deficient diet. Plasma $(A)$, erythrocyte $(B)$, and urinary $\mathrm{Mg}^{2+}(C)$ concentrations were determined by atomic absorption spectrophotometry. The results are expressed as means \pm SE of 10-16 values per group. ANOVA was performed followed by a Tukey test. $* * * P<0.001$ vs. control and $\uparrow \dagger \uparrow P<0.001$ vs. M-Def. 
sections were incubated with affinity-purified guinea pig anti-TRPM6 antiserum [1:1,500 diluted with TNB buffer (TNT buffer containing blocking reagent)] (courtesy from R. J. Bindels laboratory) (45). Biotin-labeled, affinity-purified, goat anti-guinea pig $\operatorname{IgG}(1: 2,000$; Sigma Chemical, St. Louis, MO) was used as secondary antibody, followed by incubation with streptavidin-horseradish peroxidase (1: 100; Perkin Elmer, Boston, MA). The sections were washed three times with TNT buffer (0.1 M Tris-HCL, $0.15 \mathrm{M} \mathrm{NaCL} 0.05 \%$ Tween $20 \mathrm{pH}$ 7.5) and incubated with fluorescein tyramide in amplification diluent (1:50; Perkin Elmer). Sections were washed, dehydrated in 50 to $100 \%$ ( $\mathrm{vol} / \mathrm{vol})$ methanol, and mounted in Mowiol (Hoechst, Frankfurt, Germany) containing $2.5 \%$ (wt/vol) $\mathrm{NaN}_{3}$. Micrographs of the cortex regions were acquired with a Zeiss fluorescence microscope (Sliedrecht, The Netherlands) equipped with a Nikon DMX1200 digital camera.

\section{Statistical Analysis}

Values are expressed as means \pm SE. Differences between groups were tested by the Student's $t$-test or one-way ANOVA followed by a Tukey-Kramer test. Differences were considered significant at $P<0.05$. The SigmaStat 2.0 Statistical software (SPSS Inc, Chicago IL) was used.

\section{RESULTS}

\section{Experiment 1: Dietary $\mathrm{Mg}^{2+}$ Restriction}

Blood and urine mineral analysis. The plasma $\mathrm{Mg}^{2+}$ levels were significantly lower in animals fed the mildly $(>39 \%$ reduction) and severely ( $>84 \%$ reduction) $\mathrm{Mg}^{2+}$-deficient diets compared with mice fed the control diet (Fig. 1A). Animals fed the severely $\mathrm{Mg}^{2+}$-deficient diet had significantly decreased erythrocyte $\mathrm{Mg}^{2+}$ levels (about 36\% reduction) compared with the control group (Fig. $1 B$ ). The urinary $\mathrm{Mg}^{2+}$ concentrations (corrected for creatinine) are presented in Fig. 1C. As expected, $\mathrm{Mg}^{2+}$ restriction led to hypomagnesuria in a dose-dependent manner. In addition, mice fed the severely $\mathrm{Mg}^{2+}$-deficient diet $\left(0.003 \% \mathrm{Mg}^{2+} \mathrm{wt} / \mathrm{wt}\right)$ had altered plasma and urinary mineral concentrations, including a nonsignificant reduction of plasma $\mathrm{Ca}^{2+}$ (about 12\%) and $\mathrm{K}^{+}$(about 20\%)

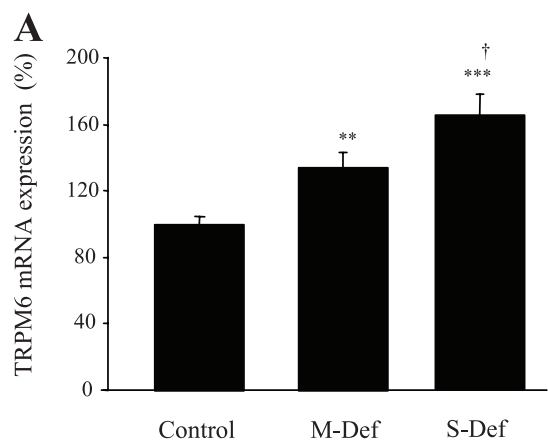

B

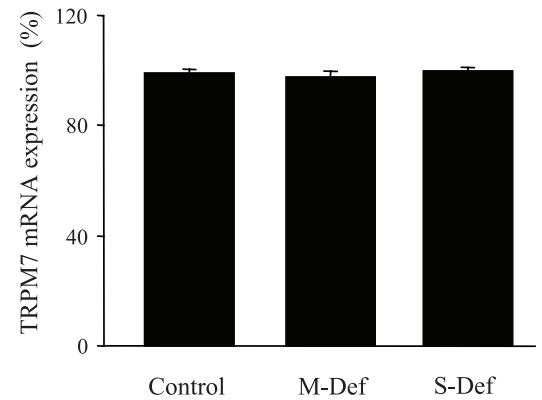

E
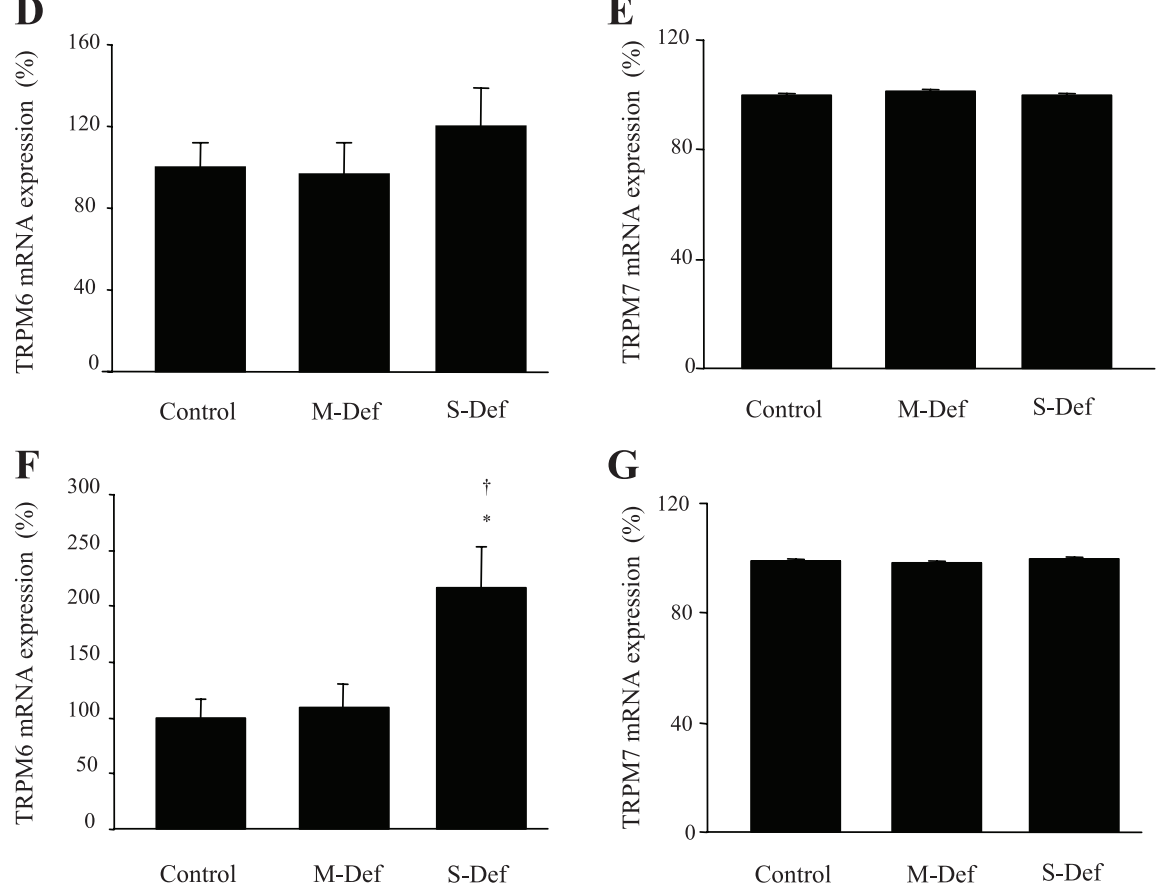

G

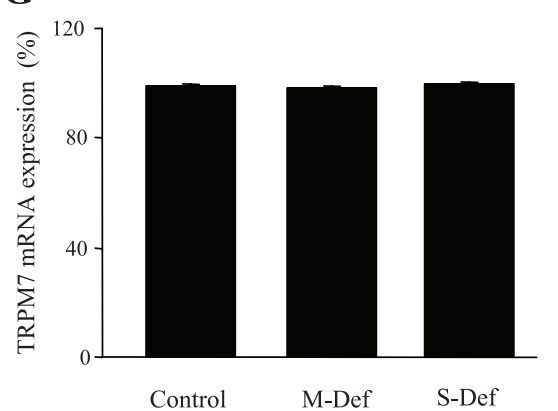

C

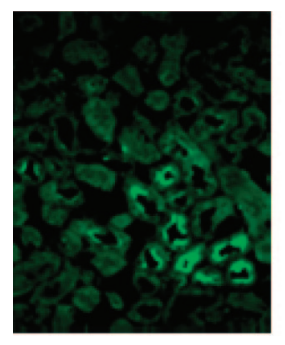

Control

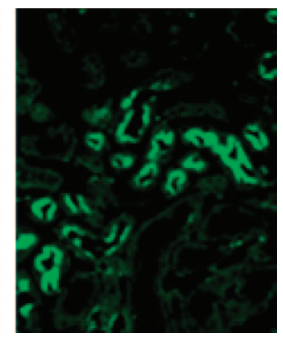

S-Def

Fig. 2. TRPM6 and TRPM7 expression in kidney and large bowel of mice fed a control, moderate (M-Def), or severely (S-Def) $\mathrm{Mg}^{2+}$-deficient diet. TRPM6 $(A)$ and TRPM7 $(B)$ mRNA level in kidney measured by RT-PCR. $C$ : immunohistochemical analysis of TRPM6 protein levels in kidney. TRPM6 $(D)$ and TRPM7 $(E)$ mRNA levels in cecum measured by RT-PCR. TRPM6 $(F)$ and TRPM7 $(G)$ mRNA levels in colon measured by RT-PCR. For the RT-PCR, the mean value of the control group was considered $100 \%$, and the results are expressed as percentage means \pm SE of 10-16 values per group. ANOVA was performed followed by a Tukey test. $* * * P<0.001, * * P<0.01$, and $* P<0.05$ vs. control, and $\uparrow P<0.05$ vs. M-Def. 
content, and increased urinary $\mathrm{Ca}^{2+}$ (about 8 -fold) and $\mathrm{K}^{+}$ (about $40 \%$ ) excretion.

Effect of dietary $\mathrm{Mg}^{2+}$ on TRPM6 and TRPM7 expression. The mildly and severely $\mathrm{Mg}^{2+}$-deficient diets induced kidney TRPM6 expression in a dose-dependent manner (Fig. 2A). IHC analysis of the kidneys confirmed that the severely $\mathrm{Mg}^{2+}$. deficient mice had increased levels of TRPM6 protein (Fig. 2C). The $\mathrm{Mg}^{2+}$-deficient diets induced no significant changes in cecum TRPM6 expression (Fig. 2D). Only the severely $\mathrm{Mg}^{2+}$-deficient diet induced TRPM6 expression in the colon (Fig. $2 F$ ). $\mathrm{Mg}^{2+}$ status had no effect on TRPM6 expression in lung (100 $\pm 7.46 \%$ compared with controls, $n=8$ /group) and TRPM7 expression in any of the studied tissues (Fig. 2, $B, E, G$ ).

\section{Experiment 2: Inbred Mice Selected for High or Low Erythrocyte $\mathrm{Mg}^{2+}$ Levels}

Blood and urine mineral analysis. $\mathrm{MgL}$ mice fed the $\mathrm{Mg}^{2+}$ adequate diet $\left(0.1 \% \mathrm{Mg}^{2+} \mathrm{wt} / \mathrm{wt}\right)$ had significantly lower $\mathrm{Mg}^{2+}$ levels in plasma and red blood cells (RBCs) $(-25 \%$ and $-22 \%$, respectively) compared with the $\mathrm{MgH}$ mice (Fig. 3, $A$ and $B$ ). Interestingly, $\mathrm{MgL}$ mice fed the control diet had higher urinary $\mathrm{Mg}^{2+}$ excretion compared with $\mathrm{MgH}$ mice $(+86 \%)$. When fed a $\mathrm{Mg}^{2+}$-adequate diet, the plasma $\mathrm{Ca}^{2+}$ levels did not differ between the $\mathrm{MgL}$ and $\mathrm{MgH}$ mice (not shown). $\mathrm{K}^{+}$plasma levels were significantly reduced in $\mathrm{MgL}$ mice $(-10 \%)$. The MgL mice had lower $\mathrm{Ca}^{2+}$ (about twofold), normal $\mathrm{K}^{+}$, and higher $\mathrm{Na}^{+}$(about 50\%) urinary excretion compared with $\mathrm{MgH}$ littermates.

When fed the severely $\mathrm{Mg}^{2+}$-deficient diet $\left(0.003 \% \mathrm{Mg}^{2+}\right.$ $\mathrm{wt} / \mathrm{wt}$ ), both the $\mathrm{MgH}$ and $\mathrm{MgL}$ mice developed hypomagnesemia $(-51 \%$ and $-75 \%$, respectively), hypomagnesuria $\left(-89 \%\right.$ and $-94 \%$, respectively), and had lower RBC $\mathrm{Mg}^{2+}$ concentrations $(-11 \%$ and $-54 \%$, respectively), compared with animals fed the (control) $\mathrm{Mg}^{2+}$-adequate diet. In the two strains, significantly different $\mathrm{Mg}^{2+}$ concentrations in plasma and RBCs were observed even on the severely $\mathrm{Mg}^{2+}$-deficient diet. Furthermore, $\mathrm{MgH}$ and $\mathrm{MgL}$ mice fed the severely $\mathrm{Mg}^{2+}$ deficient diet $\left(0.003 \% \mathrm{Mg}^{2+} \mathrm{wt} / \mathrm{wt}\right)$ had altered plasma and urinary mineral content (data not shown), including a nonsignificant reduction in plasma $\mathrm{Ca}^{2+}$ and $\mathrm{K}^{+}$concentration, and a significant reduction in urinary $\mathrm{Ca}^{2+}(-65 \%$ and $-35 \%$, respectively) and $\mathrm{Na}^{+}$excretion $(+6 \%$ and $-14 \%$, respectively), compared with mice on the control diet. These trends were exacerbated in the MgL mice.

TRPM6 and TRPM7 expression in MgL and $M g H$ mice. On the control diet, the MgL mice had significantly lower kidney TRPM6 expression (-38\%) compared with the $\mathrm{MgH}$ mice (Fig. 4A). This was confirmed by IHC analysis of the TRPM6 protein level (Fig. 4C). Similarly, cecum TRPM6 expression was reduced in the $\mathrm{MgL}$ mice $(-58 \%$; Fig. $4 D)$. The two strains showed no significant differences in colon (Fig. 4F) and lung TRPM6 expression (96.5 $\pm 7.9 \%$ in MgL compared with $\mathrm{MgH}, n=6$ /group).

In the $\mathrm{MgL}$ mice, the severely $\mathrm{Mg}^{2+}$-deficient diet $(0.003 \%$ $\mathrm{Mg}^{2+} \mathrm{wt} / \mathrm{wt}$ ) significantly induced kidney TRPM6 expression $\left(+190 \%\right.$, Fig. 4A), compared with $\mathrm{MgL}$ mice fed the $\mathrm{Mg}^{2+}$ adequate diet. In contrast, the $\mathrm{MgH}$ mice showed no change in kidney TRPM6 expression in response to these two diets. Similarly, no significant differences in TRPM6 expression
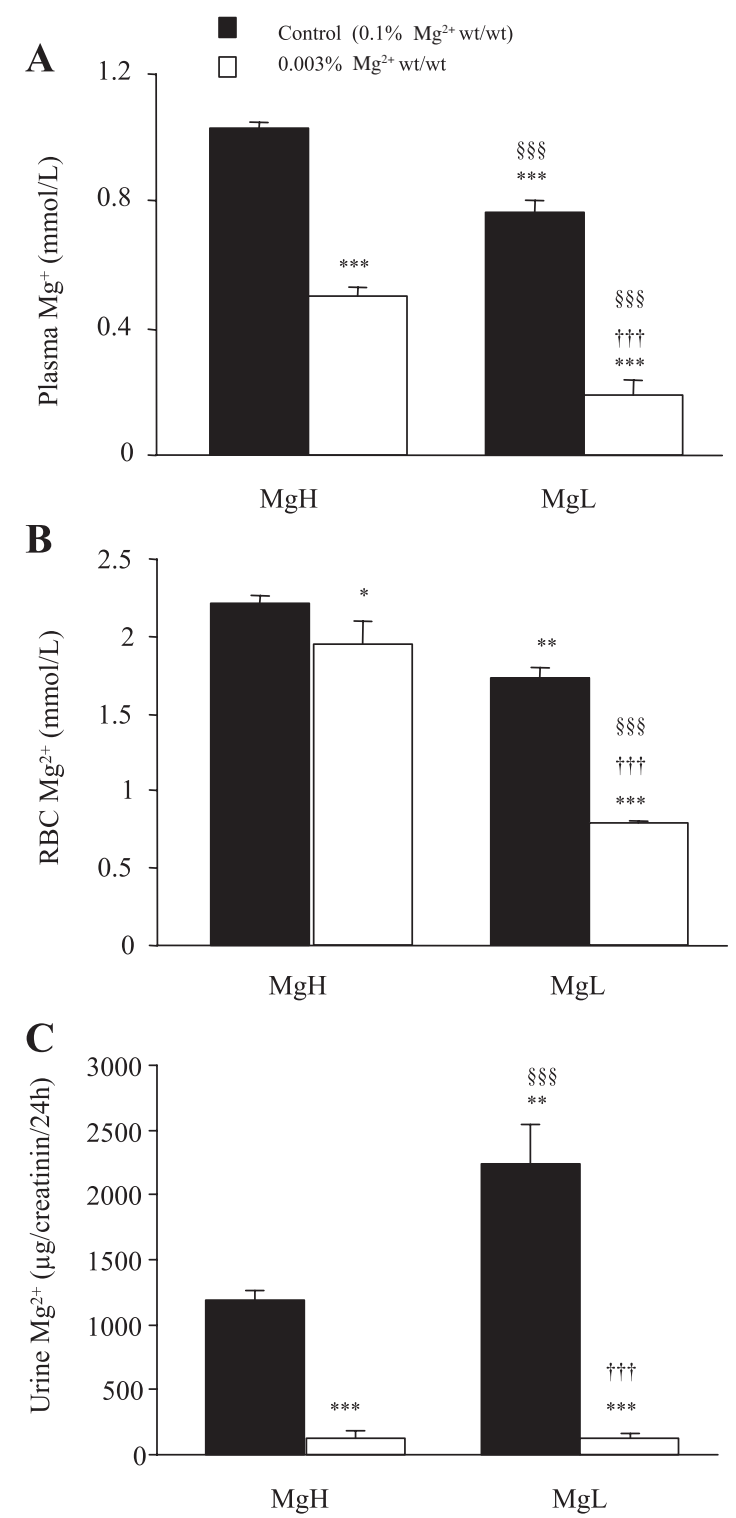

Fig. 3. Plasma, erythrocyte and urinary $\mathrm{Mg}^{2+}$ concentrations in mice selected for high $(\mathrm{MgH})$ or low $(\mathrm{MgL})$ erythrocyte $\mathrm{Mg}^{2+}$ levels, fed a control or severely (S-Def) $\mathrm{Mg}^{2+}$-deficient diet. Plasma $(A)$, erythrocytes $(B)$, and urinary $\mathrm{Mg}^{2+}(C)$ concentrations determined by atomic absorption spectrophotometry. The results are expressed as means \pm SE of 6-12 values per group. ANOVA was performed followed by a Tukey test. $* * * P<0.001$, $* * P<0.01$ and $* P<0.05$ vs. $\mathrm{MgH}$ fed a control $\mathrm{Mg}^{2+}$ diet; $\dagger \dagger \dagger P<0.001$ vs. $\mathrm{MgL}$ fed a control $\mathrm{Mg}^{2+}$ diet. $\$ \S \S P<0.001$ vs. $\mathrm{MgH}$ fed S-Def $\mathrm{Mg}^{2+}$ diet.

were observed in cecum, colon (Fig. 4, $D$ and $F$ ) and lung (not shown) when the two strains were fed the severely $\mathrm{Mg}^{2+}$ deficient diet. TRPM7 expression was unchanged in all studied tissues (Fig. 4, $B, E, G$ ).

\section{DISCUSSION}

Here, we demonstrate a strong link between TRPM6 expression and $\mathrm{Mg}^{2+}$ status in two mouse models of hypomagnesemia. TRPM6 and TRPM7 potentially contribute to the maintenance of $\mathrm{Mg}^{2+}$ homeostasis. This is supported by the fact that TRPM6 has high affinity for $\mathrm{Mg}^{2+}$, which it transports across the apical membrane of epithelial cells, thereby acting as a gatekeeper in transepithelial $\mathrm{Mg}^{2+}$ transport and uptake (3, 
$\mathbf{A}$

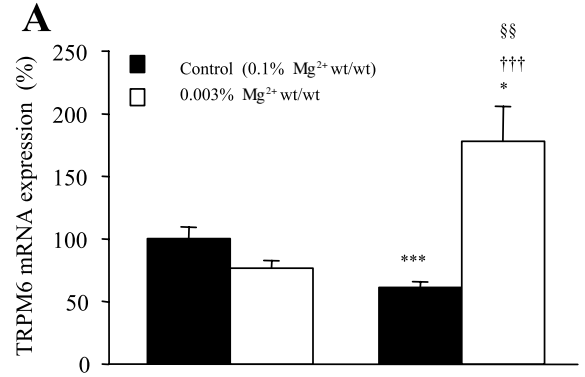

D

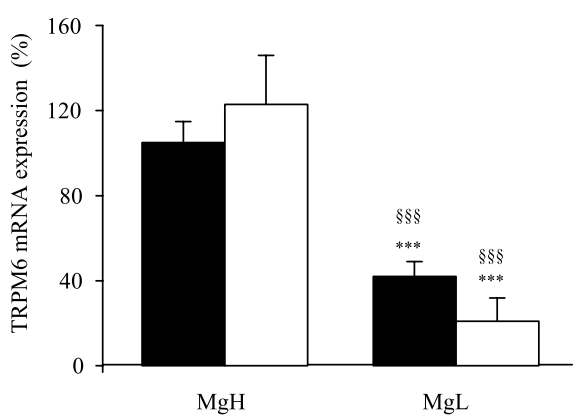

$\mathbf{F}$

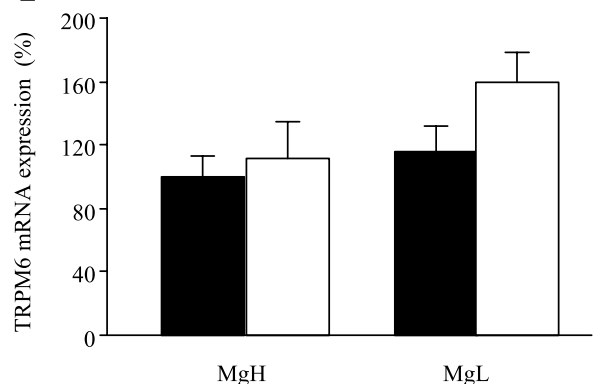

B

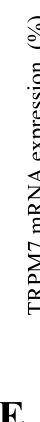

$\mathbf{E}$

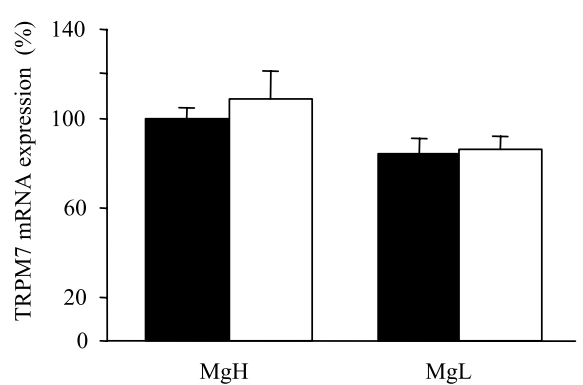

G

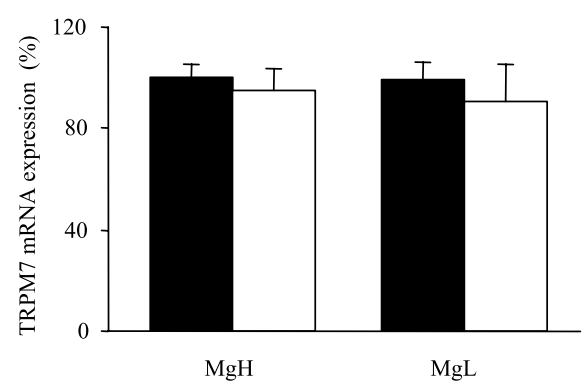

C

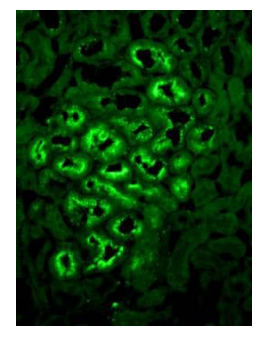

$\mathrm{MgH}$ $\left(0.1 \% \mathrm{Mg}^{2+} \mathrm{wt} / \mathrm{wt}\right)$

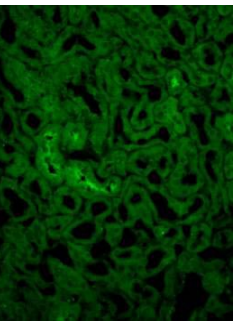

$\mathrm{MgL}$ $\left(0.1 \% \mathrm{Mg}^{2+} \mathrm{wt} / \mathrm{wt}\right)$
36, 37). Similarly, TRPM7 regulates cellular $\mathrm{Mg}^{2+}$ uptake (37). RT-PCR and in situ hybridization analyses have demonstrated that TRPM6 is expressed along the entire gastrointestinal tract, in kidney (predominantly in the DCT) (36), intestine (cecum, colon) (37), and lung $(23,27)$. It has been demonstrated that TRPM6 and TRPM7 are sensitive to intracellular $\mathrm{Mg}^{2+}$ levels (37). On the basis of these data, we designed a study to determine TRPM6 and TRPM7 expression in the kidney and intestine of two mouse hypomagnesemia models.

One part of the study was focused on a mouse model of nutritionally induced hypomagnesemia. As predicted, two low $\mathrm{Mg}^{2+}$ diets resulted in low $\mathrm{Mg}^{2+}$ levels in plasma and RBCs. This is consistent with previous results from Rude et al. (32) and our laboratory (11). The nutritionally induced $\mathrm{Mg}^{2+}$ deficiency was associated with hypomagnesuria consistent with previously published observations from animal and human studies $(2,14,29,31,40,41)$. Furthermore, graded levels of dietary $\mathrm{Mg}^{2+}$ restriction resulted in reduced $\mathrm{Mg}^{2+}$ excretion in a dose-dependent manner due to conservation of $\mathrm{Mg}^{2+}$ by the kidney.
Mice fed a severely $\mathrm{Mg}^{2+}$-deficient diet presented normokalemia, normocalcemia, hyperpotassuria, and hypercalciuria. This is consistent with previous studies of $\mathrm{Mg}^{2+}$ deficiency and associated electrolyte disturbances $(1,23,25)$. Active and passive $\mathrm{Mg}^{2+}$ transport in the kidney and intestine is regulated by hormonal and metabolic factors (23). Hormones such as aldosterone and arginine vasopressin can stimulate $\mathrm{Mg}^{2+}$ uptake in mouse distal convoluted cells $(6,7)$. Hypomagnesemia promotes aldosterone secretion, reduces $\mathrm{Na}^{+}-\mathrm{K}^{+}-$ ATPase activity, impairs parathyroid hormone release, decreases the activity of 1- $\alpha$-hydroxylase, enhances ANG II action, and consequently affects the $\mathrm{K}^{+}, \mathrm{Ca}^{2+}$, and $\mathrm{Na}^{+}$ balances $(2,16,24,30,33)$.

Here, we show that gradually increased hypomagnesuria is correlated with increased kidney TRPM6 expression. The increased kidney TRPM6 expression in the $\mathrm{Mg}^{2+}$-deficient mice is consistent with a recent study of mice fed a $\mathrm{Mg}^{2+}$-depleted diet $(0.005 \% \mathrm{wt} / \mathrm{wt})$ by Groenestege et al. (14). This observation can be explained by increased transepithelial $\mathrm{Mg}^{2+}$ transport induced by low $\mathrm{Mg}^{2+}$ status. In fact, it has been shown 
that the response to $\mathrm{Mg}^{2+}$ status change involves transcriptional/ translational control of membrane transporters $(19,29)$.

The severely $\mathrm{Mg}^{2+}$-deficient diet used in this study resulted in increased colon TRPM6 expression, whereas the mildly $\mathrm{Mg}^{2+}$-deficient diet had no effect. It has been reported that active $\mathrm{Mg}^{2+}$ transport is only important during extremely low dietary $\mathrm{Mg}^{2+}$ intake (13), and this could explain the increased expression of TRPM6 in response to the severely $\mathrm{Mg}^{2+}$. deficient diet. This is in contrast to data from Groenestege et al. (14), who showed that a $\mathrm{Mg}^{2+}$-enriched diet $\left(0.48 \% \mathrm{Mg}^{2+}\right.$ wt/ wt), but not a $\mathrm{Mg}^{2+}$-deficient diet $\left(0.005 \% \mathrm{Mg}^{2+} \mathrm{wt} / \mathrm{wt}\right)$, resulted in increased colon TRPM6 expression. These authors proposed that the absence of a specific hormonal control of $\mathrm{Mg}^{2+}$ in the intestine can explain the upregulation of TRPM6 expression in colon during high $\mathrm{Mg}^{2+}$ intake, similar to what has been described for TRPV6 in $\mathrm{Ca}^{2+}$ transepithelial absorption $(19,21)$. Moreover, in this particular study, the unaltered colon TRPM6 expression was explained by adequate intestinal $\mathrm{Mg}^{2+}$ absorptive capacity. This apparent discrepancy is likely due to differences in experimental parameters such as diet composition and regimen duration.

The severely $\mathrm{Mg}^{2+}$-deficient diet had no effect on lung TRPM6 expression. This supports the idea that $\mathrm{Mg}^{2+}$ deficiency induces selective compensatory mechanisms, increasing active $\mathrm{Mg}^{2+}$ (re)absorption at the specific sites responsible for $\mathrm{Mg}^{2+}$ homeostasis. There are no previous data showing tissuespecific modulation of TRPM6 expression. Also, given that TRPM7 expression was unperturbed, our data support a role for TRPM6 in $\mathrm{Mg}^{2+}$ homeostasis.

In the second part of this study, we used a genetic $\mathrm{Mg}^{2+}$ status model to analyze TRPM6 expression in mice with high $(\mathrm{MgH})$ or low $(\mathrm{MgL})$ erythrocyte $\mathrm{Mg}^{2+}$ levels. Consistent with previous results from our laboratory (10), the MgL mice had low $\mathrm{Mg}^{2+}$ levels in plasma and RBCs when fed a $\mathrm{Mg}^{2+}$ adequate diet $(0.1 \% \mathrm{wt} / \mathrm{wt})$. However, high levels of urinary $\mathrm{Mg}^{2+}$ were observed in the $\mathrm{MgL}$ mice when compared the $\mathrm{MgH}$ animals. Furthermore, hypokalemia, hypernatriuria, and hypocalciuria were observed in the $\mathrm{MgL}$ mice.

In the MgL mice, the observed hypermagnesuria could be due to impaired passive (paracellular) or active (transcellular) $\mathrm{Mg}^{2+}$ transport in the kidney and/or intestine. Interestingly, kidney and cecum TRPM6 expression was significantly lower in the $\mathrm{MgL}$ mice compared with the $\mathrm{MgH}$ animals. The underlying mechanism of hypomagnesemia in the $\mathrm{MgL}$ mice is undoubtedly polygenic, but reduced kidney and intestinal TRPM6 expression may contribute to the phenotype.

Consistent with previous results from our laboratory (10, 26), the severely $\mathrm{Mg}^{2+}$-deficient diet induced hypomagnesemia and low $\mathrm{Mg}^{2+}$ levels in RBCs in both mice strains, but the differences between the $\mathrm{MgH}$ and $\mathrm{MgL}$ mice persisted. The severely $\mathrm{Mg}^{2+}$-deficient diet induced and exacerbated hypocalciuria in the $\mathrm{MgH}$ mice and hyponatriuria in the $\mathrm{MgL}$ mice. Hypomagnesuria was a common finding in both strains when fed the severely $\mathrm{Mg}^{2+}$-deficient diet. Similar to the nutritionally induced $\mathrm{Mg}^{2+}$ deficiency in C57BL/6J mice, MgL mice fed the severely $\mathrm{Mg}^{2+}$-deficient diet had increased kidney TRPM6 expression, which was not observed in the $\mathrm{MgH}$ mice. In both strains, intestinal TRPM6 expression was unaffected by the $\mathrm{Mg}^{2+}$-deficient diets.

The MgL mice showed higher sensitivity to $\mathrm{Mg}^{2+}$ restriction than the $\mathrm{MgH}$ mice and had a greater adaptive response, increasing the kidney TRPM6 level more than twofold. This is consistent with the fact that the kidney is the major organ responsible for $\mathrm{Mg}^{2+}$ homeostasis (29) and could explain the specific upregulation of kidney TRPM6 expression during $\mathrm{Mg}^{2+}$ deficiency in $\mathrm{MgL}$ mice. It is possible that the two strains show different genetic responses to changes in cellular $\mathrm{Mg}^{2+}$ content and that the $\mathrm{MgL}$ mice have a lower $\mathrm{Mg}^{2+}$ threshold, resulting in a more pronounced response to $\mathrm{Mg}^{2+}$ deficiency.

From a comparative point of view, the low $\mathrm{Mg}^{2+}$ mouse phenotype is different from that observed in HSH patients that carry TRPM6 mutations and have pronounced hypomagnesemia. A high dose of oral $\mathrm{Mg}^{2+}$ supplementation can reestablish normal $\mathrm{Mg}^{2+}$ levels in these patients, which shows that there is no defect in the passive transport protein paracellin-1 (19).

In conclusion, dietary $\mathrm{Mg}^{2+}$ restriction and hypomagnesemia can positively alter renal and intestinal $\mathrm{Mg}^{2+}$ absorption by improving active $\mathrm{Mg}^{2+}$ transport and modulating TRPM6 expression. TRPM6 expression is sensitive to the extracellular $\mathrm{Mg}^{2+}$ concentration in kidney and intestine. No differences were observed in TRPM6 expression in lung under any of the studied conditions. TRPM7 expression was not affected in the different models. Our results support the idea that TRPM7 function is independent of TRPM6. TRPM6 and TRPM7 appear functionally nonredundant (38), but both may be involved in the process of epithelial $\mathrm{Mg}^{2+}$ transport and absorption. The inbred $\mathrm{MgL}$ and $\mathrm{MgH}$ mice represent an interesting model for studying genetically determined $\mathrm{Mg}^{2+}$ homeostasis. It clearly appears that their response to dietary $\mathrm{Mg}^{2+}$ differs, but at present, the reasons for this are not understood.

\section{Perspectives and Significance}

Our observations strengthen the evidence that TRPM6 expression in epithelial cells is an important player of the genetic system involved in the maintenance of $\mathrm{Mg}^{2+}$ homeostasis. Further studies are required to accurately determine the physiological roles of TRPM6 and TRPM7, and to further our understanding of the complex networks that control $\mathrm{Mg}^{2+}$ homeostasis. This knowledge will also contribute to elucidate the origin and consequences of differences in $\mathrm{Mg}^{2+}$ status between individuals.

\section{ACKNOWLEDGMENTS}

We wish to thank D. Bayle, S. Thien, and J. C. Tressol for technical assistance.

\section{GRANTS}

This work was supported in part (to AM) by Prix de Recherche du Centre Evian pour l'Eau.

\section{REFERENCES}

1. Berkelhammer C, Bear RA. A clinical approach to common electrolyte problems: 4. Hypomagnesemia. Can Med Assoc J 132: 360-368, 1985.

2. Carney SL, Wong NL, Quamme GA, Dirks JH. Effect of magnesium deficiency on renal magnesium and calcium transport in the rat. J Clin Invest 65: 180-188, 1980.

3. Chubanov V, Gudermann T, Schlingmann KP. Essential role for TRPM6 in epithelial magnesium transport and body magnesium homeostasis. Pflügers Arch 451: 228-234, 2005.

4. Chubanov V, Waldegger S, Mederos y Schnitzler M, Vitzthum H, Sassen MC, Seyberth HW, Konrad M, Gudermann T. Disruption of 
TRPM6/TRPM7 complex formation by a mutation in the TRPM6 gene causes hypomagnesemia with secondary hypocalcemia. Proc Natl Acad Sci USA 101: 2894-2899, 2004.

5. Cole DE, Quamme GA. Inherited disorders of renal magnesium handling. J Am Soc Nephrol 11: 1937-1947, 2000.

6. Dai LJ, Bapty B, Ritchie G, Quamme GA. Glucagon and arginine vasopressin stimulate $\mathrm{Mg}^{2+}$ uptake in mouse distal convoluted tubule cells. Am J Physiol Renal Physiol 274: F328-F335, 1998.

7. Dai LJ, Ritchie G, Bapty B, Quamme GA. Aldosterone potentiates hormone-stimulated $\mathrm{Mg}^{2+}$ uptake in distal convoluted tubule cells. Am J Physiol Renal Physiol 274: F336-F341, 1998.

8. Dai LJ, Ritchie G, Kerstan D, Kang HS, Cole DE, Quamme GA. Magnesium transport in the renal distal convoluted tubule. Physiol Rev 81: 51-84, 2001.

9. Feillet-Coudray C, Coudray C, Tressol JC, Pepin D, Mazur A, Abrams SA, Rayssiguier Y. Exchangeable magnesium pool masses in healthy women: effects of magnesium supplementation. Am J Clin Nutr 75: 72-78, 2002.

10. Feillet-Coudray C, Coudray C, Wolf FI, Henrotte JG, Rayssiguier Y, Mazur A. Magnesium metabolism in mice selected for high and low erythrocyte magnesium levels. Metabolism 53: 660-665, 2004.

11. Feillet-Coudray C, Trzeciakiewicz A, Coudray C, Rambeau M, Chanson A, Rayssiguier Y, Opolski A, Wolf FI, Mazur A. Erythrocyte magnesium fluxes in mice with nutritionally and genetically low magnesium status. Eur J Nutr 45: 171-177, 2006.

12. Finckenberg $\mathbf{P}$, Merasto $\mathbf{S}$, Louhelainen $\mathbf{M}$, Lindgren $\mathbf{L}$, Vapaatalo $\mathbf{H}$, Muller DN, Luft FC, Mervaala EM. Magnesium supplementation prevents angiotensin II-induced myocardial damage and CTGF overexpression. J Hypertens 23: 375-380, 2005.

13. Fine KD, Santa Ana CA, Porter JL, Fordtran JS. Intestinal absorption of magnesium from food and supplements. J Clin Invest 88: 396-402, 1991.

14. Groenestege WM, Hoenderop JG, van den Heuvel L, Knoers N, Bindels RJ. The epithelial $\mathrm{Mg}^{2+}$ channel transient receptor potential melastatin 6 is regulated by dietary $\mathrm{Mg}^{2+}$ content and estrogens. J Am Soc Nephrol 17: 1035-1043, 2006.

15. Gwanyanya A, Amuzescu B, Zakharov SI, Macianskiene R, Sipido KR, Bolotina VM, Vereecke J, Mubagwa K. Magnesium-inhibited, TRPM6/7-like channel in cardiac myocytes: permeation of divalent cations and pH-mediated regulation. J Physiol 559: 761-776, 2004.

16. He Y, Yao G, Savoia C, Touyz RM. Transient receptor potential melastatin 7 ion channels regulate magnesium homeostasis in vascular smooth muscle cells: role of angiotensin II. Circ Res 96: 207-215, 2005

17. Henrotte JG, Franck G, Santarromana M, Frances H, Mouton D, Motta R. Mice selected for low and high blood magnesium levels: a new model for stress studies. Physiol Behav 61: 653-658, 1997.

18. Henrotte JG, Pla M, Dausset J. HLA- and H-2-associated variations of intra- and extracellular magnesium content. Proc Natl Acad Sci USA 87: 1894-1898, 1990.

19. Hoenderop JG, Bindels RJ. Epithelial $\mathrm{Ca}^{2+}$ and $\mathrm{Mg}^{2+}$ channels in health and disease. J Am Soc Nephrol 16: 15-26, 2005.

20. Hoenderop JG, Hartog A, Stuiver M, Doucet A, Willems PH, Bindels RJ. Localization of the epithelial $\mathrm{Ca}(2+)$ channel in rabbit kidney and intestine. J Am Soc Nephrol 11: 1171-1178, 2000.

21. Hoenderop JG, Nilius B, Bindels RJ. Calcium absorption across epithelia. Physiol Rev 85: 373-422, 2005.

22. Konrad M, Schlingmann K, Gudermann T. Insights into the molecular nature of magnesium homeostasis. Am J Physiol Renal Physiol 286 F599-F605, 2004.

23. Konrad M, Weber S. Recent advances in molecular genetics of hereditary magnesium-losing disorders. J Am Soc Nephrol 14: 249-260, 2003.

24. Laurant P, Dalle M, Berthelot A, Rayssiguier Y. Time-course of the change in blood pressure level in magnesium-deficient Wistar rats. $\mathrm{Br} \mathrm{J}$ Nutr 82: 243-251, 1999.

25. Nadler J, Rude R. Disorders of magnesium metabolism. Endocrinol Metab Clin North Am 24: 623-641, 1995.
26. Ozgo M, Bayle D, Zimowska W, Mazur A. Effect of a low magnesium diet on magnesium status and gene expression in the kidneys of mice selected for high and low magnesium erythrocyte levels. Magnes Res 20: $148-153,2007$.

27. Pedersen SF, Owsianik G, Nilius B. TRP channels: an overview. Cell Calcium 38: 233-252, 2005.

28. Quamme GA. Renal magnesium handling: new insights in understanding old problems. Kidney Int 52: 1180-1195, 1997.

29. Quamme GA, de Rouffignac C. Epithelial magnesium transport and regulation by the kidney. Front Biosci 5: D694-D711, 2000.

30. Ritchie G, Kerstan D, Dai LJ, Kang HS, Canaff L, Hendy GN, Quamme GA. $1,25(\mathrm{OH})(2) \mathrm{D}(3)$ stimulates $\mathrm{Mg}^{2+}$ uptake into MDCT cells: modulation by extracellular $\mathrm{Ca}^{2+}$ and $\mathrm{Mg}^{2+}$. Am J Physiol Renal Physiol 280: F868-F878, 2001.

31. Rude RK. Magnesium deficiency: a cause of heterogeneous disease in humans. J Bone Miner Res 13: 749-758, 1998.

32. Rude RK, Kirchen ME, Gruber HE, Meyer MH, Luck JS, Crawford DL. Magnesium deficiency-induced osteoporosis in the rat: uncoupling of bone formation and bone resorption. Magnes Res 12: 257-267, 1999.

33. Rude RK, Oldham SB, Sharp CF Jr, Singer FR. Parathyroid hormone secretion in magnesium deficiency. J Clin Endocrinol Metab 47: 800806, 1978.

34. Schimatschek HF, Rempis R. Prevalence of hypomagnesemia in an unselected German population of 16,000 individuals. Magnes Res 14: 283-290, 2001.

35. Schlingmann KP, Konrad M, Seyberth HW. Genetics of hereditary disorders of magnesium homeostasis. Pediatr Nephrol 19: 13-25, 2004.

36. Schlingmann KP, Weber S, Peters M, Niemann Nejsum L, Vitzthum H, Klingel K, Kratz M, Haddad E, Ristoff E, Dinour D, Syrrou M, Nielsen S, Sassen M, Waldegger S, Seyberth HW, Konrad M. Hypomagnesemia with secondary hypocalcemia is caused by mutations in TRPM6, a new member of the TRPM gene family. Nat Genet 31: 166-170, 2002.

37. Schmitz C, Deason F, Perraud A. Molecular components of vertebrate $\mathrm{Mg}^{2+}$-homeostasis regulation. Magnes Res 20: 6-18, 2007.

38. Schmitz C, Dorovkov MV, Zhao X, Davenport BJ, Ryazanov AG, Perraud AL. The channel kinases TRPM6 and TRPM7 are functionally nonredundant. J Biol Chem 280: 37763-37771, 2005.

39. Schmitz C, Perraud AL, Fleig A, Scharenberg AM. Dual-function ion channel/protein kinases: novel components of vertebrate magnesium regulatory mechanisms. Pediatr Res 55: 734-737, 2004.

40. Shafik IM, Quamme GA. Early adaptation of renal magnesium reabsorption in response to magnesium restriction. Am J Physiol Renal Fluid Electrolyte Physiol 257: F974-F977, 1989.

41. Shils ME. Experimental human magnesium depletion. Medicine (Baltimore) 48: 61-85, 1969.

42. Takezawa R, Schmitz C, Demeuse P, Scharenberg AM, Penner R, Fleig A. Receptor-mediated regulation of the TRPM7 channel through its endogenous protein kinase domain. Proc Natl Acad Sci USA 101: 6009_ 6014, 2004.

43. Touyz RM, He Y, Montezano AC, Yao G, Chubanov V, Gudermann T, Callera GE. Differential regulation of transient receptor potential melastatin 6 and 7 cation channels by ANG II in vascular smooth muscle cells from spontaneously hypertensive rats. Am J Physiol Regul Integr Comp Physiol 290: R73-R78, 2006.

44. Van Abel M, Hoenderop JG, Dardenne O, St Arnaud R, Van Os CH, Van Leeuwen HJ, Bindels RJ. 1,25-dihydroxyvitamin D(3)-independent stimulatory effect of estrogen on the expression of $\mathrm{ECaC} 1$ in the kidney. J Am Soc Nephrol 13: 2102-2109, 2002.

45. Voets T, Nilius B, Hoefs S, van der Kemp AW, Droogmans G, Bindels RJ, Hoenderop JG. TRPM6 forms the $\mathrm{Mg}^{2+}$ influx channel involved in intestinal and renal $\mathrm{Mg}^{2+}$ absorption. J Biol Chem 279: 19-25, 2004.

46. Walder RY, Landau D, Meyer P, Shalev H, Tsolia M, Borochowitz Z, Boettger MB, Beck GE, Englehardt RK, Carmi R, Sheffield VC. Mutation of TRPM6 causes familial hypomagnesemia with secondary hypocalcemia. Nat Genet 31: 171-174, 2002. 